\title{
Syllabus Design and Needs Analysis of Students in Educational System
}

\author{
Zahra Bazyar \\ Department of Foreign Languages and Linguistic, Vali-e-Asr University of Rafsanjan, Rafsanjan, Iran \\ E-mail: Bazyar.academic@gmail.com \\ Mehdi Dastpak (Corresponding author) \\ Department of Foreign Languages, Jahrom University of Medical Sciences, Jahrom, Iran \\ E-mail: Md dataforse@yahoo.com \\ Ali Taghinezhad \\ Department of Foreign Languages and Linguistics, Shiraz University, Shiraz, Iran \\ E-mail: taghinezhad1@gmail.com
}

Doi:10.7575/aiac.alls.v.6n.4p.162

Received: 04/04/2015

URL: http://dx.doi.org/10.7575/aiac.alls.v.6n.4p.162

Accepted: 09/06/2015

\begin{abstract}
A syllabus is a plan showing the subjects or books to be studied in a particular course, especially a course that leads to an exam. There are various syllabuses available for different purposes. This article represents the classification of syllabuses regarding different authors' views and perspectives. The aim of this article, after depicting available syllabuses, is to state that in order to have the most useful syllabus in education, one which results in the best learning outcome for the students, the educational system should take its selection principles based on students' needs.
\end{abstract}

Keywords: syllabus design, needs analysis, educational system

\section{Introduction}

A syllabus is a well-written description; it is a plan about what to be included in the course for the learning objectives. Pienemann (1985) sees the syllabus as the selection and grading of linguistic teaching objectives. Breen (1984) sees it a plan of what is to be achieved through our teaching and our students' learning. And Candlin' view about syllabus is that: "Syllabuses are concerned with the specification and planning of what is to be learned, frequently set down in some written form as prescriptions for action by teachers and learners. They have, traditionally, the mark of authority. They are concerned with the achievement of ends, often, though not always, associated with the pursuance of particular means"' (Candlin, 1984).

For a syllabus to be effective, Littlefield (1999a) suggests 7 purposes: a setting tone for a course, a type of motivation for students to reach their academic goals, a planning tool for faculty, a structuring tool of the students' work, and a contract between faculty and students about their expectations. Stec (2011) identifies five factors for syllabus implementation: lesson aims, content, procedures, syllabus users (teachers, learners), and teaching materials.

\section{Syllabus classifications}

\subsection{Schools in syllabus design}

There are three important views about syllabus design: Lancaster school, London school, and Toronto school.

The first trend, Lancaster school, which is represented by Candlin and Breen (1980), has reacted against the notion of a fixed syllabus which can be planned, pre-ordained, and imposed on teachers and students. A matter of focus for this group is not a choice between structure and functional syllabus. Every syllabus for this group is regarded as open and negotiable (This group believes that the curriculum would be negotiated by the teacher and a group of learners).

The second trend, London school, is represented by Brumfit (1984) and Widdowson (1987). This school argues that the Lancaster view is extreme and unrealistic. This group put forward what they considered a more realistic approach. According to Widdowson, a syllabus is necessary, economical, and thus useful. Like Candlin and Breen, he agrees with the idea of freedom for the teacher. He makes a distinction between syllabus and teaching methodology. Brumfit's beliefs are similar to Widdowson's idea as well. He sees a curriculum as a public statement serving all kinds of practical purposes. According to his view, a syllabus should be based on language, language learning, and language use.

The third trend, Yalden's formulation (1984), is a bridge between the London school viewpoints and is called the Toronto School. She identifies the theoretical underpinnings of the syllabus content, which is similar to Brumfit's view. She doesn't agree with the learner's role in syllabus development, believing that the syllabus is primarily a teacher's statement about objectives and content. 


\subsection{Major syllabuses}

There are six major types of syllabuses, proposed by Krahnke (1987), which can be implemented in various teaching situations:

A structural syllabus is a syllabus in which input is selected according to grammatical notions of simplicity and complexity. This syllabus includes a collection of the forms and structures, usually grammatical elements such as verbs, nouns, and so on.

A notional/functional syllabus is based on communicative functions such as requesting, suggesting and agreeing. The content of the language in this syllabus is a collection of the functions that are to be performed when language is used, or of the notions that language is used to express. When first encountered the terms function and notion, many teachers are confused. In fact functions may be described as the communicative purposes for which we use language, while notions are the concept.

A situational syllabus is based on the language needed for different situations such as at the airport or restaurant. It is an alternative to the grammatical syllabus. In this type of syllabus, a series of situations will form the organizing principle, and each situation is associated with a particular activity or task.

A skill-based syllabus is organized around different abilities in a language which are used for different purposes such as reading. Learning a complex activity like listening is composed of skills and micro-skills.

A content-based syllabus is not really a syllabus. It is organized around different themes, topics and other units of content. In this type of syllabus, the primary purpose of the instruction is to teach some content using the language that the students are learning. An example is a history class taught in the language the students need or want to learn.

A task-based syllabus involves a series of complex and purposeful tasks that students complete in the target language.

\subsection{Merits and demerits of syllabuses}

Structural syllabus selects patterns based on the time available, arranges the items into sequences to facilitate learning, and identifies grammatical items to allow for the development of communicative skills; but the problem is that this syllabus represents a partial dimension of language proficiency.

Notional/functional syllabus provides a convenient framework for the design of teaching materials especially in listening and speaking. But grading functions has no clear criteria in this syllabus.

In situational syllabus, language is taught in context, but this language, which is used in a specific situation, may not be transferred to other situations.

In skill-based syllabus, skills are transferable to other situations, but there is no specific basis for determining skills.

Content-based syllabus addresses the students' needs and motivates them. A problem with this syllabus is that it is hard to qualify ESL teachers to teach such a course.

Problems with task-based syllabus is in its designing and selection. Another problem is that in this syllabus more focus is on fluency than accuracy.

\subsection{Synthetic and analytic syllabuses}

Syllabuses can be characterized as being synthetic or analytic (Wilkins, 1976). In synthetic syllabuses different parts of language are taught separately so that acquisition is gradual accumulation of parts until the whole structure of language has been built up. The language that is mastered in one unit of learning, adds to previously learned units. According to Rabbini (2002), these syllabuses focus on what the learners will know at the end of instruction session.

Wilkins (1976) indicated that the role of the learner is "to re-synthesize the language that has been broken down into a large number of small pieces with the aim of making his learning task easier". He also argued that components of language are seen as "building blocks which have to be carefully accumulated" where there is "careful linguistic control of the learning environment". Synthetic approaches to syllabus design characterize many traditional language courses and textbooks. Structural, lexical, notional/functional, and most situational and topical syllabuses are synthetic.

Wilkins (1976) states analytic syllabus as "prior analysis of the total language system into discrete pieces of language that is a necessary precondition for the adoption of a synthetic approach is largely superfluous.... Analytic approaches $\ldots$ are organized in terms of the purposes for which people are learning language and the kinds of language performance that are necessary to meet those purposes".

Analytic refers not to what the syllabus designer does, but to the operations required of the learner to analyze the linguistic components of the language chunks. These types of syllabuses are more likely to result from the use of experiential rather than linguistic content. Process-, procedural-, and task-based syllabuses are analytic.

Another name which Wilkins (1976) has given to synthetic syllabuses and analytic syllabuses is product-oriented syllabuses and process-oriented syllabuses respectively. Product-oriented syllabuses emphasize the product of language learning. Initially, some people equated synthetic syllabuses with grammatical syllabuses; but then, some applied linguists feel that the term synthetic need not necessarily be restricted to grammatical syllabuses, but may be applied to any syllabus in which the content is product-oriented.

According to Rabbini (2002), the process-oriented syllabuses developed as a result of a sense of failure in productoriented syllabuses to enhance communicative language skills. In these types of syllabuses, the focus is not on what the student will have accomplished on completion of the program, but on the specification of learning tasks and activities that $\mathrm{s} / \mathrm{he}$ will undertake during the course of study. 


\subsection{Type $A$ and type B syllabuses}

From another perspective, White (1988) explains that all current syllabuses fall under two categories: Type A and Type B syllabuses. Type A syllabuses deal with what should be learned in a second language classroom. Most syllabuses that fall under 'Type A' syllabus are best represented by controlled practice, sequentially presenting language items one at a time, whereby learners are expected to build a gradual understanding of language. Here, the teacher is the authority in the classroom. He decides about what items the students must learn and how they will be evaluated. So, things are done to the learner. As it is clear from the definition of this type of syllabus, it is product-oriented synthetic syllabus.

Type B syllabuses consider the question of how a second language should be learned. Here, the emphasis is on the learning process. Objectives of the course are based on the needs of the learners. The teacher and students work together. So, things are done with the learners. This type of syllabus is useful for the author in developing learners' communicative skills. Type B syllabuses stand for Process-oriented analytic syllabuses. White categorizes content or skills-based syllabuses as type A and process and the procedural syllabuses as type B (White, 1988).

\subsection{Proportional syllabus}

Wilkins (1976) described analytic and synthetic syllabuses as proportional syllabus. He argues that Syllabuses that support second language curricula are never completely synthetic or analytic. Yalden (1987) states that "three principles which inform language syllabus design are (1) a view of how language is learned, which could result in a structurebased syllabus; (2) a view of how language is acquired, which would result in a process-based syllabus; and (3) a view of how language is used, which would result in a function-based syllabus." By integrating the three views, Yalden (1983) proposes a proportional syllabus, with a semantic-grammatical organizational base, a linguistic component based on language functions, and themes based on learners' interests. According to Yalden (1983), a proportional syllabus comprises a blend of structural and functional elements. In this syllabus, the focus shifts from linguistic form to communicative function as the program progresses. This shift from form to interaction can occur at any time and is not limited to learner ability. This syllabus basically attempts to develop an overall competence.

\subsubsection{Merits}

The benefits of a proportional syllabus are that it overcomes the problem of reconciling functional and structural demands; it offers a close interweaving of structural and non-structural, systematic and non-systematic elements over time (Yalden, 1983).

\subsection{Variable focus syllabus}

Allen (1984) has devised a syllabus named variable focus syllabus which emphasizes the importance of using a hybrid type of syllabus by language teachers in the classroom. This syllabus is similar to Yalden's proportional syllabus. Allen's formulation of the variable focus syllabus consists of three components: structural, functional and experiential. This syllabus includes all levels in all the time, but the emphasis changes at different stages of learning. Yalden (1987) represents the advantage of this model when she states that "it would seem to allow the syllabus designer the most freedom to respond to changing or newly perceived needs in the learners, and at the same time provides a framework for the teacher who may not be able or willing to go fully communicative..."

\section{Top-down and bottom-up processes in the syllabus design}

Wilkins (1976) identifies two philosophies about syllabus design: a specialist approach (top-down process) and a learner-centered approach (bottom-up process). Paradigms of the top-down syllabus are content, organization, and presentation through synthesis or analysis. With regard to content, Wilkins (1976) states that: there are limits to what can be achieved through grammatical and situational syllabuses, both leave the learner short of communicative capacity. Organization often focuses on ideas of comparative difficulty. Larsen (1974) notes that learners may need to use 'difficult' structures earlier than a difficulty-oriented syllabus introduces them. Larsen thus offers utility as a possible principle of syllabus sequencing, although there are problems in discovering what is more or less useful for learners. In the part of presentation Wilkins (1976) claims that there probably exist flaws in the synthesis and analysis approaches, synthesis seems to leave learners short of communicative competence until re-synthesis takes place, while analysis leaves them unprepared for anything out of the ordinary due to its approximation of the learners' own linguistic behavior. As Johnson (1989) argues, the specialist approach includes expert input, clear formulation of objectives and perhaps most importantly, they are also transferable (i.e. they can be used by teachers and learners other than those involved in their initial development). A problem with the top-down syllabus is that it includes one-way flow of information and the lack of interaction with the learner (Johnson, 1989). In this type of syllabus, learners are regarded as passive agents in the classroom.

In the learner-centered approach to syllabus design, the focus is on the learner. The learners are as a key participant in the learning process, and provide a theoretical basis for negotiated contributions or interaction to syllabus development (Prabhu, 1992 \& Allwright, 1984). They are regarded as active agents in the classroom (this is the basic difference between top-down and bottom-up syllabuses).

Interaction focuses on more than just content. Candlin (1984) maintains that purpose, method, content, and evaluation are all negotiable within learner-centered syllabus, as "the how becomes interconnected with the what". Although, negotiation means that the syllabus cannot be written at the start of the course, the process can start with a pre-defined syllabus or also several syllabuses. 


\section{Syllabus design based on the needs analysis}

Syllabus designers and material developers conduct the designing of syllabuses based on educational implications and what they consider as significant for the students in every level of education they are. Based on this procedure, students have to learn what is imposed on them by syllabus designers not what they really need for their learning which can be applicable for their real life out of classroom. Wilkins (1981) states that "starting from an awareness of the learners and their needs, it is proposed that from the total set those categories should be selected that are relevant to the particular population of learners." According to this view, designing syllabuses should be based on needs analysis of the students. Needs analysis is a family of procedures for gathering information about learners and communication tasks for use in syllabus design.

With regard to the needs analysis, White (1988) states "the teacher or planner investigates the language required for performing a given role or roles.... needs analysis specifies the ends which a learner hopes to achieve, but not the means by which the ends will be reached." So teachers and syllabus designers should take into account what students really need, rather than what they think they need to learn and master.

\section{Discussion and Conclusion}

A glimpse at the literature of language teaching reveals that many books and papers have been written about syllabus design and curriculum development in recent decades. In this paper, it has been attempted to depict all valuable syllabuses. It also took a look at syllabus design based on the needs of the students. Its main purpose was to say that educational system should not think that the skills which students need to learn and use out of classroom are just skills relevant to educational and occupational purposes. It should be borne in mind that language is a whole system based on which the whole parts should be taught. Syllabus designers in education should not concentrate on the product-oriented syllabuses at the expense of process-oriented ones. They should integrate both types of syllabuses in order that students have the most effective learning. According to Hutchinson and Waters (1987, p. 51) words, "It is wise to take an eclectic approach, taking what is useful from each theory and trusting also in the evidence of your own experience as a teacher". By taking an eclectic approach, the syllabus designers can do away with the disadvantages of each approach and meet the needs of the learners. By taking into account the communicative part of language, type B syllabuses especially task-based syllabus should be included in the syllabus design. Students should be given time to take part in group activities and group discussions, to give their opinions about ways and methods of teaching. Richards and Rodgers (1986:69) argue that if assumptions about the nature of linguistics and language learning is one of "language as communication" then a syllabus based around activities and tasks which promote real and meaningful communication will seem advantageous. There should also be a shift away from specialist approach toward the learner-centered approach. By giving questionnaire or having pretest, teachers should know what the students' needs are, and teach language in accordance with those needs.

The best way to have the most effective and appealing learning in students is to integrate both types of syllabuses, i.e., proportional syllabus, and listen to the students' needs. But there are some problems the most important of which is about the time. Listening to the needs and teaching students based on their needs takes more time than traditional teaching. But a point to regard is that since nowadays English language has a major role in society, education should give more time to English language classes in schools. Through this way, the classroom atmosphere will be more appealing, students will be more enthusiastic about taking part in classes, and a high level of learning will take place.

\section{References}

A.Mine Tokatl1, Y. K. (2009). Syllabus: how much does it contribute to the effective communication with the students? Social and Behavioral Sciences , 4.

Asghar Salimi, S. D. (2012). Critical review of approaches to foreign language syllabus design: task-based Syllabus (a shortcut). Social and Behavioral Sciences, 5.

Flowerdew, L. (2005). Integrating traditional and critical approaches to syllabus design: the 'what', the 'how' and the 'why?'. English for Academic Purposes, 13.

Hasan, A. S. (2007). The Envisaged Syllabus for Teaching English as a Foreign Language. Damascus University Journal, 23(2), 17.

Hutchinson, T., \& Waters, A. (1987). English for specific purposes: A learning-centered approach. Cambridge University Press.

Jambor, P. Z. (2006). 'Synthetic and Analytic Syllabuses'. Department of Education, Art \& Design, 25.

Prabhu, N. S. (1992). The Dynamics of the Language Lesson. TESOL International Association, 26 (2), 221-418.

Rabbini, R. (2002). An Introduction to Syllabus Design and Evaluation. The Internet TESL Journal, 8(5).

Rahimpour, M. (2010). Current trends on syllabus design in foreign language instruction. Social and Behavioral Sciences, 5 .

Raine, P. (2010). a discussion of notional-functional syllabus. Unpublished manuscript, University of Birmingham, Birmingham, UK.

Saeid Najafi Sarem, H. H. (2012). The Proportional Syllabus: A Better Alternative to the Existing Syllabus Types in LanguageCurriculum Design in EFL Contexts. Advances in English Linguistics (AEL), 1(3), 5.

Stec, M. (2011). Early language teaching and syllabuses . Social and Behavioral Sciences, 10.

Wilkins, D. (1976). Notional syllabuses. London: Oxford University Press, 7(2), 111-116. 